\title{
EFFECTIVENESS OF LARVA MONITORING TRAINING ON KNOWLEDGE OF DENGUE HEMORRAGIC FEVER CONTROL AMONG PRIMARY SCHOOL STUDENTS IN SIBOLGA, NORTH SUMATERA
}

\author{
Wandi Damanik, Nurmaini, Kintoko Rochadi \\ Master Programs in Public Health, Universitas Sumatera Utara
}

\begin{abstract}
Background: Dengue fever/dengue hemorrhagic fever (DHF) is one of the most important public health problems in tropical developing countries. It also has major economic and societal consequences. This study aimed to assess the effectiveness of larva monitoring training on knowledge of dengue hemorragic fever control among primary school students in Sibolga, North Sumatera.

Subjects and Method: This was a quasi-experiment before and after with no controlled design. The study was conducted in elementary school in Sibolga, North Sumatera, in 2018. A sample of 30 students was selected for this study and received training on DHF for four days. The training employed leaflet, video, and photocopied materials. The dependent variable was knowledge on DHF. The independent variable was training on DHF. The data were collected by questionnaire and tested by t-test.

Results: Knowledge on DHF among students increased by Mean= 26.67 (SD= 14.51) after training, and it was statistically significant ( $\mathrm{p}=0.037)$.

Conclusion: Knowledge on DHF among students increases after training, and it is statistically significant.
\end{abstract}

Keywords: training, knowledge, dengue hemorrhagic fever

\section{Correspondence:}

Wandi Damanik. Master Programs in Public Health, Universitas Sumatera Utara, Medan, North Sumatera. Email: wandidamanik4981@gmail.com.

Mobile: 081376602949 